\title{
EXPERT ASSESSMENT OF MEDICAL CARE IN CASES OF INJURY, ILLNESS AND POISONING IN DIFFERENT DEPARTMENTS OF HOSPITAL OF AMBULANCE MEDICAL CARE
}

\author{
Pletenetska A., Gurina O., Popov V. A., Roshin G.
}

\begin{abstract}
Summary. One of the most complex forensic examinations is the determination of the correct medical care. The aim of the study was an analysis of medical records of patients in the cases of divergence of clinical and forensic diagnoses on the main complications and to identify the main causes of incorrect diagnosis established in a hospital of ambulance medical care for the 2006 2012. Expert assessment of mortality General Hospital was carried out after statistical data processing, including a more detailed study of patient care. In particular, stood out the reasons of incorrectly clinical diagnosis, cases of discrepancy of the main clinical diagnosis with forensic diagnosis were compared in cases of injury, disease or poisoning. After that evaluated medical care, including medical treatment, which was prescribed by a doctor. These data were compared with those which medical aid was really necessary in patients with considering the immediate cause of death.
\end{abstract}

Keywords: forensic examination, medical care, injury, dise.

УДК: 616.12-005.4-073.55

\section{ДОСЛІДЖЕННЯ БІОЛОГІЧНИХ ТКАНИН І РІДКИХ СЕРЕДОВИЩ ОРГАНІЗМУ ЛЮДИНИ ЛАЗЕРНИМИ ПОЛЯРИМЕТРИЧНИМИ МЕТОДАМИ}

\author{
СБачинський В. Т., Ушенко О. Г., Ванчуляк О. Я., Саркісова Ю. В. \\ Кафедра судової медицини та медичного правознавства \\ Буковинський державний медичний університет, Чернівці
}

Резюме. У статті представлений сучасний стан питання діагностики патологічних станів для судово-медичних експертів практиків. Особливу увагу приділено біофізичними методам дослідження, які володіють доказовою точністю, об'єктивністю, відтворюваністю та високою швидкістю отримання результату. Перспективним, на наш погляд, є дослідження рідких середовищ організму людини, зокрема скловидного тіла, методами лазерної поляриметрії, що дозволяють виявити та впровадити в практику новітні оптичні критерії діагностики давності настання смерті. не тіло.

Ключові слова: лазерна поляриметрія, давність настання смерті, час формування гематом, ішемія міокарда, скловид-

ВСТУП. За останні роки ми спостерігаємо тенденцію до розвитку нових сучасних методик дослідження біологічних тканин (БТ) і середовищ організму (СО) людини. Зокрема в судово-медичній практиці існує низка питань, які не можуть бути вирішені без розробки нових підходів до діагностики патологічних станів.

Одним із потужних методів досліджень структури і властивостей препаратів БТ та СО є поляризаційна мікроскопія (ПМ). ІІЇ використання можливе на основі того, що всі тканин організму людини можна представити, як сукупність оптично одноосних протеїнових фібрил, що володіють здатністю подвійного променезаломлення та формують його унікальну структурно-функціональну організацію $[11,13]$.

Для реалізації методу ПМ можна дооснастити будь-який мікроскоп: додати два поляризаційні фільтри (перший поміщають безпосередньо під конденсором, другий - між об'єктивом і оком дослідника). Для затемнення поля зору проводять поворот поляризатора, в подальшому зміщують досліджуваний об'єкт на предметному столику до появи яскравого світіння (воно з'являється в момент перебування вісі двопроменезаломлюючого об’ єкта під кутом $45^{\circ}$ до площини поляризації) [9].

ПМ на етапах свого розвитку пройшла поступове удосконаленням методики: спочатку застосування фільтрів із лінійною, а в подальшому - з циркулярною поляризацією. Встановлено, що зображення, отримані за допомогою циркулярних фільтрів, несуть набагато більше інформації, дозволяють більш детально вивчити структуру тканин $[9,12]$.

Протягом останніх років ПМ шляхом міжгалузевої інтеграції медицини, оптичної фізики та аналітичної математики трансформувалась у лазерну поляриметрію. Колективом кафедри судової медицини та медичного правознавства Буковинського державного медичного університету та кафедри оптики та спектроскопії інженернотехнічного факультету Чернівецького національного університету імені Ю. Федьковича було прийняте рішення, слідуючи за загальносвітовою тенденцією, впровадити дану методику в галузь судово-медичної діагностики та розробити принципово новий підхід для вирішення складних завдань в практиці судово-медичних експертів. Дана методика забезпечує потужну діагностичну цінність у поєднанні з об'єктивністю, відтворюваністю та швидкістю отримання результату $[1,2,4]$. 
Таким чином, дослідниками були розроблені об'єктивні новітні лазерні поляриметричні критерії діагностики прижиттєвих та посмертних змін БТ і СО людини для вирішення складних завдань судово-медичної практики, зокрема встановлення давності настання смерті при різних ii видах, часу формування гематом, прижиттєвості утворення тілесних ушкоджень, діагностики гострої ішемії міокарда.

Так було отримано взаємозв'язок між зажиттєвістю чи післясмертністю утворення саден та статистичними (середнє і дисперсія) і просторово-частотними (дисперсія екстремумів Log-log залежностей спектрів потужності) параметрами, що характеризують координатні розподіли інтенсивності, азимутів, еліптичності, фазових зсувів між ортогональними компонентами лазерної хвилі в зображеннях шкіри людини [2]. Статистично достовірна різниця для зміни середнього - від 1 до 130 годин, а для зміни дисперсії - від 1 до 100 годин).

Також розроблено комплекс лазерних поляриметричних методів діагностики БТ трупа людини для точного визначення давності настання смерті (ДНС). Для цього авторами було вивчено динамічні закономірні зміни структури поляризаційних зображень БТ людини в часовій динаміці у післясмертному періоді. Комплексне застосування сукупності поляризаційного, матричного, статистичного та автокореляційного аналізу розподілів поляризаційних параметрів лазерних зображень гістологічних зрізів БТ трупа дозволяє залежно від їх виду визначати ДНС в термін від 1 до 140 год, при похибці 1-1,5 год [5].

Ще одним напрямком досліджень було визначення діагностичної ефективності лазерної поляриметрії гематом внутрішніх органів для судово-медичного встановлення часу їх виникнення. Гематоми різної локалізації мають координатно неоднорідну та індивідуальну структуру внаслідок їх багатошарової будови. Для діагностики давності їх формування ефективним $€$ використання показників координатних розподілів станів поляризації, ступеня деполяризації та фазових зсувів лазерних поляризаційних зображень гематом [1].

Також встановлено діагностичні можливості лазерної поляриметрії для судово-медичної діагностики гострої коронарної недостатності (ГКН). Досліджено азимутально-незалежні поляризаційні мапи мікроскопічних зображень, мюллер-матричні зображення полікристалічних фібрилярних міозинових мереж; взаємозв'язки між набором статистичних, кореляційних і фрактальних параметрів, які характеризують розподіли значень поляризаційних мап, мюллер-матричних зображень із ішемічними змінами міокарда померлих внаслідок ГКН; розподіли інтенсивності зображень автофлуоресценції зрізів міокарда; операційні характеристики (чутливість, специфічність, збалансована точність) діагностичної ефективності багатопараметричної мікроскопічної та автофлуоресцентної посмертної діагностики ішемії міокарда [4]. Результати досліджень дозволяють не лише діагностувати ГКН, але диференціювати з іншими патологічними станами, коли звичайні методи гістологічного дослідження є неефективними.

Висока точність та відтворюваність результатів лазерних поляриметричних методик дослідження покладає можливість подальшого удосконалення отриманих результатів. Зокрема перспективним $є$ уточнення ДНС шляхом лазерного поляриметричного аналізу скловидного тіла (СТ).

Як відомо, СТ на 98\% складається з води, решта: гіалуронова кислота, колагенові волокна (колаген II i IX типів) і білки [10]. Саме рідка колагенова сітка у поєднанні з вираженою здатністю гіалуронової кислоти зв'язувати воду обумовлюють гомогенну желеподібну консистенцію і прозорість СТ [7]. Також в ньому присутні клітини - гіалоцити, котрі беруть участь в синтезі гіалуронової кислоти, ретикуліну (попередника колагену) i розчинних білків. Каркас скловидного тіла утворений тонкою мережею волокон білка колагену різних форм, що переплітаються між собою. Проміжки між волокнами заповнені рідиною $[8,10]$.

3 точки зору механіки СТ підтримує певний рівень внутрішньоочного тиску і забезпечує нормальне прилягання внутрішніх оболонок ока. СТ є прозорим оформленим гелем об’ємом близько 4 мл, що складається 3 рідких фракцій і плівчастих структур. Гель сформований колагеновою фібрилярною стромою і пов'язаним з нею в'язким розчином гіалуронової кислоти [3]. За сучасними уявленнями основна маса СТ містить воронкоподібні комплекси видимих мембранел (тонкі волокнисті пластинки, що відбивають світло) - вітреальні тракти. Така структура надає СТ людини властивостей оптико-одновісних рідких кристалів, що дозволяє досліджувати його лазерними поляриметричними методами [12].

3 оптичної точки зору СТ являє собою багатокомпонентну рідину, до складу якої входять дві основні фракції: оптично ізотропна - оптично гомогенний комплекс гіалуронової кислоти з білками та гіалоцитами; оптично анізотропна - рідкокристалічна фаза, що складається із сукупності рідких кристалів різних типів: фібринових ниток, колагенових волокон [12].

Виходячи із запропонованої моделі структури СТ можна припустити, що в процесі їх зондування лазерним випромінюванням одночасно будуть формуватися оптично-ізотропні складові зображення, що відповідає координатному розподілу ізотропних складових СТ, та поляризаційно неоднорідні складові зображення, зумовлені впливами оптично анізотропних рідкокристалічних структурних елементів [6, 12].

Таким чином можна дослідити головні посмертні оптичні зміни СТ людини при різних термінах настання смерті, які пов'язані із трансформацією його оптико-анізотропної структури. 


\title{
ВИСНОВКИ:
}

1.Враховуючи стрімкий науково-технологічний прогрес, ми вважаємо доцільною розробку та впровадження в практику судово-медичних експертів сучасних лазерних поляриметричних методів діагностики, так як вони є найбільш перспективними серед інших методів досліджень сьогодення.

2.На підставі отриманих результатів розробки і реалізації лазерних поляризаційних методів, ми можемо зробити висновок, що подальше їх використання дозволить нам відкрити нові перспективи у вивченні біологічних тканин, рідин, середовищ людського тіла для вирішення нагальних проблем судово-медичної науки і практики.

3.Для судово-медичної діагностики встановлення термінів настання смерті, лазерні поляриметричні методи дослідження відрізняються високою чутливістю та достовірністю, що в сукупності з таким об’єктом, як скловидне тіло доводить перспективність подальшого їх вивчення.

\section{Література}

1. Бачинський В.Т. Визначення давності настання смерті та часу утворення гематом методами лазерної спектрофотополяриметрії / В.Т. Бачинський, Б.В. Михайличенко, В.Д. Мішалов, О.Г. Ушенко. - Чернівці: Прут, 2011. - 325 с. : іл., табл. - Бібліогр.: С. 308-325.

2. Беженар І.Л. Судово-медична діагностика зажиттєвих та посмертних ушкоджень шкіри людини шляхом аналізу спектрів потужності інтенсивності їі поляризаційних зображень / І.Л. Беженар // Український судово-медичний вісник. - 2007. - №1. - С.25-31.

3. Буйнов А.А. Стекловидное тело глаза человека как объект для судебно-медицинского исследования / А.А. Буйнов // Материалы международной научно-практической конференции. - Минск, 2016. - С. 38-40.

4. Ванчуляк О.Я. Можливості використання кореляційного фазового лазерного аналізу для діагностики структурних змін міокарда / О.Я. Ванчуляк // Вісник Вінницького національного медичного університету. - 2015. - Т.19, №2. - С.325-330.

5. Ванчуляк О.Я. Діагностика давності настання смерті методом лазерного поляриметричного моніторингу тканин людини: автореф. дис. на здобуття наук. ступеня канд. мед. наук: 14.01.25. / О.Я.Ванчуляк. К.: НМАПО ім. П.Л.Шупика, 2007. - 20 с.

6. Ермакова Ю.В. К вопросу о диагностике давности наступления смерти при исследовании стекловидного тела / Ю.В. Ермакова //Медицинская экспертиза и право. - 2011. - № 2. - С. 25-27.

7. Морфофункциональные особенности стекловидного тела / С.И. Харлап, Т.А. Щеголева, Д.В. Анджелова, А.Ф. Фахрутдинова // Вестник офтальмологии. - 2012. - Т. 128, № 3. - С. 48-54.

8. Онянов А. М. Обоснованность выбора стекловидного тела в качестве объекта судебно-медицинских исследований / А.М. Онянов, И.А. Ледянкина, С.В. Хохлов // Проблемы экспертизы в медицине. - 2007. - Т. 7 , № 28-4. - С. 64-67.

9. Основи лазерної поляриметрії: Патоморфологічні зміни біологічних тканин / О.Г. Ушенко, В.Т. Бачинський, О.Я. Ванчуляк, І.Л. Беженар // - Чернівці: Чернівецький нац. ун-т, 2010. - 372с.

10. Рева Г.В. Структура стекловидного тела глаза человека / Г.В. Рева, И.В. Рева, Т. Ямамото // Тихоокеанский медицинский журнал. - 2011. - №1. - С. 65-69.

11. Optical methods of investigation in forensic practice / V.T. Bachinsky, O.Y. Vanchulyak, A.I. Zavolovich [et al.] // Info-Med Revistă ştiinţifico-practică. - 2014. - P.32-33.

12. Statistical and Fractal Processing of Phase Images of Human Biological Fluids / Yu.O. Ushenko, Yu.Ya. Tomka, Yu.I. Marchuk, V.O. Balanetcka // Advances in Electrical and Computer Engineering. - 2010. - Vol. 10, № 4. - P. 161-166.

13. Ushenko V.O. Polarization correlometry of polycrystalline films of human liquids in problems of forensic medicine / V.O. Ushenko, O.V. Olar, Yu.O. Ushenko [at al.] // Proc.SPIE. - 2015. - Vol. 9809. - 98091B-98091B-6.

\section{ИССЛЕДОВАНИЕ БИОЛОГИЧЕСКИХ ТКАНЕЙ И ЖИДКИХ СРЕД ОРГАНИЗМА ЧЕЛОВЕКА ЛАЗЕРНЫМИ ПОЛЯРИМЕТРИЧЕСКИМИ МЕТОДАМИ}

\author{
В. Т. Бачинский, О. Г. Ушенко, О. Я. Ванчуляк, Ю. В. Саркисова
}

Резюме. В статье представлено современное состояние вопроса диагностики патологических состояний для судебномедицинских экспертов практиков. Особое внимание уделено биофизическим методам исследования, которые обладают доказательной точностью, объективностью, воспроизводимостью и высокой скоростью получения результата. Перспективным, на наш взгляд, является исследование жидких сред организма человека, в том числе стекловидного тела, методами лазерной поляриметрии, что позволит обнаружить и внедрить в практику новейшие оптические критерии диагностики давности наступления смерти.

Ключевые слова: лазерная поляриметрия, давность наступления смерти, время формирования гематом, ишемия миокарда, стекловидное тело. 


\title{
THE STUDY OF BIOLOGICAL TISSUES AND BODILY FLUIDS OF THE HUMAN BODY USING LASER POLARIMETRIY
}

\author{
V. T. Bachinskiy, O. G. Ushenko, O. Y. Vanchulyak, Y. V. Sarkisova
}

Summary. The article presents the current status of questions concerning the diagnosis of pathological conditions for forensic practitioners. Particular attention is paid to biophysical research methods, which have evidential accuracy, objectivity, reproducibility and fast results. In our opinion, a promising direction is the study of bodily fluids, including the vitreous body, is laser polarimetry techniques that will help identify and introduce the newest optical criteria for diagnosing time of death.

Keywords: laser polarimetry, time of death, formation of hematomas, myocardial ischemia, vitreous body.

УДК 616.718-001.5-091:611.718

\section{НОВИЙ ПОГЛЯД НА БІОМЕХАНІКУ ПЕРЕЛОМІВ ДОВГИХ ТРУБЧАСТИХ КІСТОК НИЖНЬОї КІНЦІВКИ}

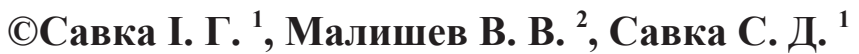 \\ ${ }^{1}$ ВДНЗ України «Буковинський державний медичний університет», \\ ${ }^{2}$ Чернівецьке обласне бюро судово-медичної експертизи, м. Чернівці
}

Резюме. Основною метою нашої роботи є розгляд сучасних аспектів біомеханіки переломів довгих трубчастих кісток нижньої кінцівки при механічній травмі. В якості об'єктів дослідження виступили 576 зразків та 128 експертних випадків 3 ушкодженнями стегнової, велико- та малогомілкової кісток. Отримані дані піддані статистичній обробці 3 використанням багатофакторного дисперсійного аналізу. У роботі встановлено, що для визначення механо- та морфогенезу переломів довгих трубчастих кісток нижньої кінцівки найбільш доцільно використовувати три згруповані ієрархічні біомеханічні модулі: пружності, жорсткості та міцності, які включають найвагоміші діагностичні значимі морфологічні ознаки, згруповані за ступенем їх впливу на процеси руйнації вказаних кісток.

Ключові слова: нижня кінцівка, довгі трубчасті кістки, переломи, морфологічні ознаки, біомеханіка травми.

ВСТУП. На сучасному етапі розвитку судово-медичної науки біомеханіка переломів включає вирішення комплексу спеціальних завдань. По перше - це встановлення параметрів засобу, що спричинив перелом. Зазвичай, фахівці вирішують це питання за морфологічними особливостями різних зон руйнації кістки та видами деформацій, які спричинив травмуючий предмет. По друге - це врахування анатомо-функціональних особливостей кісткової тканини, що сприймає навантаження. Загальновідомо, що структурно-функціональні особливості травмованої кістки чинять суттєвий вплив, а в ряді випадків є визначальними у виникненні морфологічної картини переломів різних кісток скелета людини. Насамкінець, лікарі судово-медичні експерти та криміналісти мають максимально точно і повно відновити умови за яких відбулася взаємодія травмуючого предмета і травмованої ділянки.

Фактори, що формують вказані комплекси достатньо повно описані та проілюстровані в діагностикумі механізмів і морфології переломів при тупій травмі скелета - монографії, виданій під керівництвом професора Крюкова В.Н. [1].

У той же час, сучасні методи дослідження кісткової тканини, комп'ютерної візуалізації ділянки перелому, статистичної обробки значного об’єму цифрового матеріалу, що всебічно характеризують морфологічні ознаки різних зон ділянки перелому довгих трубчастих кісток та їх структурні особливості - дозволяють поглибити знання, які розкривають біомеханіку переломів вказаних кісток і вивести нові закономірності у перебігу процесу їх руйнації.

Також все більше закордонних науковців у своїх дослідженнях вказують на необхідності біомеханічних досліджень процесу руйнації довгих кісток нижньої кінцівки та впливу окремих морфологічних компонентів кісткової тканини на перебіг процесу їх руйнації: G.E. Sroga, V. Kosmopoulos, S. Nagaraja, E.I. Waldorff та iн. [2, 3, 4, 5].

Мета дослідження. Розглянути сучасні аспекти біомеханіки переломів довгих трубчастих кісток нижньої кінцівки при механічній травмі, для об’єктивного ретроспективного встановлення механізмів їх виникнення.

Матеріал і методи дослідження. В якості матеріалу дослідження взяті 576 зразків стегнової, велико- і малогомілкової кісток, що вилучені із 16-ти біоманекенів чоловічої та жіночої статей віком від 24 до 70 років без ïx травматичних ушкоджень, видимих патологічних змін чи згадок про такі в анамнезі. Експертні дослідження включали 82 особи зі 128 ушкодженнями нижніх кінцівок: стегна - 40 випадків, великогомілкової кістки - 46 випадків, малогомілкової - 42 випадки. Отримані дані піддавали статистичній обробці з використанням багатофакторного дисперсійного аналізу. 